See discussions, stats, and author profiles for this publication at: https://www.researchgate.net/publication/325852392

\title{
Enhancement of hydrogen production rate by high biomass concentrations of Thermotoga neapolitana
}

Article in International Journal of Hydrogen Energy · June 2018

Dol: 10.1016/.j.jhydene.2018.05.072

CITATIONS

11

6 authors, including:

G Gilbert Dreschke

U. Università degli studi di Cassino e del Lazio Meridionale 8 PUBLICATIONS 93 CITATIONS

SEE PROFILE

Antonio Panico

Università degli Studi della Campania "Luigi Vanvitelli

68 PUBLICATIONS 2,425 CITATIONS

SEE PROFILE

Some of the authors of this publication are also working on these related projects:

Effect of nitrate and sulfate on selenate bioreduction and influence of $\mathrm{pH}$ on reactor operation View project

Total Synthesis of Natural products View project
Giuliana d'Ippolito

Italian National Research Council

113 PUBLICATIONS 2,494 CITATIONS

SEE PROFILE

P.N.L. Lens

IHE Delft Institute for Water Education

986 PUBLICATIONS 26,765 CITATIONS

SEE PROFILE 


\title{
Enhancement of hydrogen production rate by high biomass concentrations of Thermotoga neapolitana
}

\author{
Gilbert Dreschke ${ }^{a, b, *}$, Giuliana d'Ippolito ${ }^{b}$, Antonio Panico ${ }^{c}$, \\ Piet N.L. Lens ${ }^{d}$, Giovanni Esposito ${ }^{a}$, Angelo Fontana ${ }^{b}$ \\ a Department of Civil and Mechanical Engineering, University of Cassino and Southern Lazio, Via Di Biasio, 43, \\ 03043, Cassino, FR, Italy \\ ${ }^{\mathrm{b}}$ Bio-Organic Chemistry Unit, Institute of Biomolecular Chemistry, Italian National Council of Research, Via Campi \\ Flegrei 34, 80078, Pozzuoli, Napoli, Italy \\ c Telematic University Pegaso, Piazza Trieste e Trento, 48, 80132, Naples, Italy \\ d UNESCO - IHE Institute for Water Education, Westvest 7, 2611-AX Delft, The Netherlands
}

\section{A R T I C L E I N F O}

\section{Article history:}

Received 23 February 2018

Received in revised form

28 April 2018

Accepted 13 May 2018

Available online 19 June 2018

\section{Keywords:}

\section{Hydrogen}

Thermotoga neapolitana

Biomass concentration

Dark fermentation

Hyperthermophilic

\begin{abstract}
A B S T R A C T
The objective of this study was to enhance the hydrogen production rate of dark fermentation in batch operation. For the first time, the hyperthermophilic pure culture of Thermotoga neapolitana cf. Capnolactica was applied at elevated biomass concentrations. The increase of the initial biomass concentration from 0.46 to $1.74 \mathrm{~g}$ cell dry weight/L led to a general acceleration of the fermentation process, reducing the fermentation time of $5 \mathrm{~g}$ glucose/L down to $3 \mathrm{~h}$ with a lag phase of $0.4 \mathrm{~h}$. The volumetric hydrogen production rate increased from $323( \pm 11)$ to $654( \pm 30) \mathrm{mL} / \mathrm{L} / \mathrm{h}$ with a concomitant enhancement of the biomass growth and glucose consumption rate. The hydrogen yield of $2.45( \pm 0.09) \mathrm{mol} \mathrm{H}_{2} /$ mol glucose, the hydrogen concentration of $68 \%$ in the produced gas and the composition of the end products in the digestate, i.e. $62.3( \pm 2.5) \%$ acetic acid, $23.5( \pm 2.9) \%$ lactic acid and $2.3( \pm 0.1) \%$ alanine, remained unaffected at increasing biomass concentrations.

๑ 2018 Hydrogen Energy Publications LLC. Published by Elsevier Ltd. All rights reserved.
\end{abstract}

\section{Introduction}

Hydrogen $\left(\mathrm{H}_{2}\right)$ is a non-polluting and clean fuel of the future with a wide range of applications [1,2]. The demand for hydrogen is continuously increasing and expected to contribute $8-10 \%$ to the energy market by 2025 [1].
Biotechnological hydrogen production processes have advanced in recent years and revealed promising results for an environmentally friendly production route $[1,3]$. Dark fermentation is thereby considered as the most attractive process due to its simplicity, independence of light and the potential to use substrates from renewable sources. However, the low $\mathrm{H}_{2}$ production rate observed in dark fermentation still

Abbreviations: CDW, Cell dry weight [g/L]; HPR, Hydrogen production rate; AA, Acetic acid; LA, Lactic acid.

* Corresponding author. Department of Civil and Mechanical Engineering, University of Cassino and Southern Lazio, Via Di Biasio, 43, 03043, Cassino, FR, Italy.

E-mail addresses: gilbert.dreschke@icb.cnr.it (G. Dreschke), gdippolito@icb.cnr.it (G. d'Ippolito), antonio.panico@unipegaso.it (A. Panico), p.lens@unesco-ihe.org (P.N.L. Lens), giovanni.esposito@unicas.it (G. Esposito), afontana@icb.cnr.it (A. Fontana). 
remains a fundamental challenge [4-6]. The hydrogen production rate (HPR) is crucial for the production at industrial scale [7] and a considerable increase is required for the establishment of an economically viable process [8,9].

Thermotoga neapolitana is a hyperthermophilic organism with a great potential for hydrogen production through dark fermentation [10]. This bacterium grows on a wide range of substrates including glucose, fructose, xylose, maltose, starch, glycogen, glycerol, molasses, cheese whey, algal biomass and carrot pulp [11-15]. The microorganism has fast growth kinetics [16], oxygen tolerance [14] and low contamination risks due to the extreme culture conditions at $80^{\circ} \mathrm{C}$ [17]. Previous studies using Thermotoga neapolitana have primarily focused on the optimization of the hydrogen yield in batch fermentation [14,18-20]. Yields approaching the theoretical $4 \mathrm{~mol} \mathrm{H}_{2} /$ mol glucose have been reached when applying $5-10 \%$ of inoculum (v/v) $[2,14,21]$. Promising results of Thermotoga neapolitana in attached growth [22-24] further emphasize the potential of the organism, indicating towards a possible use in a biofilm reactor system. However, low HPRs between 23 and $50 \mathrm{~mL} / \mathrm{L} / \mathrm{h}$ observed in simple batch cultivation using Thermotoga neapolitana [14] demonstrate the need for further development.

Despite the lower $\mathrm{H}_{2}$ yields, the highest HPRs are currently reached under mesophilic conditions due to their capability to grow in high biomass concentrations [25]. A positive correlation was demonstrated between the HPR and the biomass concentration in the reactor in continuous dark fermentations [6]. Hyperthermophilic cultures reach much higher hydrogen yields [26], but they commonly grow in low cell densities [5] leading to low $\mathrm{H}_{2}$ production rates. A substantial improvement of the HPR is expected if hyperthermophilic cultures are cultivated at high biomass concentrations $[25,27]$. In batch cultivation of suspended cell, high biomass concentrations are generally implemented by the recycling of biomass, which enables a faster and more robust process [27].

In the present study, a suspended culture of pure Thermotoga neapolitana biomass was used at different concentrations ranging from 0.46 to $1.74 \mathrm{~g} / \mathrm{L}$ to mimic a sequential batch fermentation described by Basso et al. [28]. The main objective was to induce an acceleration of the dark fermentation process, in particular the HPR. Simultaneously, the effect of elevated biomass concentrations on the efficiency of the process and the kinetics of hydrogen production, glucose consumption and biomass growth were evaluated.

\section{Material and methods}

\section{Culture medium}

A modified ATCC 1977 culture medium as described by d'Ippolito et al. [19] was used for the cultivation of Thermotoga neapolitana containing the following components (in $\mathrm{g} / \mathrm{L}$ ): 10 $\mathrm{NaCl}$; 5 glucose; 2 yeast extract; 2 tryptone; 1 cysteine; $1 \mathrm{NH}_{4} \mathrm{Cl}$; $0.3 \quad \mathrm{~K}_{2} \mathrm{HPO}_{4} ; 0.3 \quad \mathrm{KH}_{2} \mathrm{PO}_{4} ; 0.2 \quad \mathrm{MgCl}_{2} \cdot 6 \mathrm{H}_{2} \mathrm{O} ; 0.1 \mathrm{KCl} ; 0.1$ $\mathrm{CaCl}_{2} \cdot 2 \mathrm{H}_{2} \mathrm{O} ; 0.001$ resazurin dissolved in distilled water, supplemented with $10 \mathrm{~mL} / \mathrm{L}$ of vitamin and $10 \mathrm{~mL} / \mathrm{L}$ of trace element solutions (DSM medium 141).

\section{Bacterial strain - cultivation and storage}

A pure culture of Thermotoga neapolitana cf. Capnolactica [29] (hereafter briefly Thermotoga neapolitana) was used in all experiments. For the conservation of the culture, $120 \mathrm{~mL}$ serum bottles containing $25 \mathrm{~mL}$ of culture medium were prepared. Prior to the inoculation, the medium was heated to remove excess oxygen until losing the characteristic resazurin color, sealed immediately with butyl rubber stoppers and sterilized by autoclaving for $5 \mathrm{~min}$ at $110{ }^{\circ} \mathrm{C}$ [19]. The medium was inoculated using $6 \%(\mathrm{v} / \mathrm{v})$ of stored cell cultures. After the cultivation at $80{ }^{\circ} \mathrm{C}$ without agitation overnight, the grown culture was stored at $4{ }^{\circ} \mathrm{C}[30]$.

\section{Preparation of inoculum}

The inoculum was produced in two $3 \mathrm{~L}$ continuously stirred tank reactors (Applikon Biotechnology, The Netherlands) each containing $2000 \mathrm{~mL}$ of culture medium. The medium was heated to $80^{\circ} \mathrm{C}$ and sparged with $\mathrm{CO}_{2}$ for $5 \mathrm{~min}$ to remove the dissolved oxygen. Subsequently, the $\mathrm{pH}$ was adjusted to 7 by addition of $1 \mathrm{M} \mathrm{NaOH}$ and the reactors were inoculated using $6 \% \mathrm{v} / \mathrm{v}$ of stored culture (described in 2.2). The cultivation was performed at $80^{\circ} \mathrm{C}$ and $200 \mathrm{rpm}$ for $14.5 \mathrm{~h}$ to obtain a culture at the end of the stationary phase where the amount of active biomass reaches its maximum. The biomass was harvested by centrifugation at $3750 \mathrm{rpm}$ for $15 \mathrm{~min}$ and resuspended in an isotonic solution (10 g/L NaCl in distilled water) to produce a highly concentrated inoculum ( $1 \mathrm{~mL}$ of inoculum contains biomass of $50 \mathrm{~mL}$ of grown culture). The biomass concentration in $\mathrm{g} C D W / \mathrm{L}$ of each sampling point was estimated from the optical density at $540 \mathrm{~nm}\left(\mathrm{OD}_{540}\right)$ using the relation CDW $[g / L]=0.269 \times O_{540}-0.061\left(R^{2}=0,98\right)[20,31]$.

\section{Experimental design}

Eight $250 \mathrm{~mL}$ Schott flasks, each containing $200 \mathrm{~mL}$ of culture medium were used to investigate the hydrogen production from a Thermotoga neapolitana culture at increasing biomass concentrations. Prior to inoculation, the medium was heated to $80^{\circ} \mathrm{C}$, sparged with $\mathrm{CO}_{2}$ for $5 \mathrm{~min}$ to remove oxygen and the $\mathrm{pH}$ adjusted to 7 by addition of $1 \mathrm{M} \mathrm{NaOH}$, being the optimum $\mathrm{pH}$ for hydrogen production by Thermotoga neapolitana [32]. A volumetric ratio of inoculum to culture medium $(\mathrm{v} / \mathrm{v})$ is commonly used to describe the amount of inoculum applied. Considering this ratio, the concentrated inoculum (described in 2.3) was used to inoculate the reactors between 100 and $400 \% \mathrm{v} / \mathrm{v}$ (100\% corresponding to biomass harvested from $200 \mathrm{ml}$ of grown culture in $200 \mathrm{ml}$ of fresh medium): C1 - 100\% (=0.46 g CDW/L), C2 - 200\% (=0.91 g CDW/L), C3 - 300\% (= $1.33 \mathrm{~g} \mathrm{CDW} / \mathrm{L})$ and $\mathrm{C} 4-400 \%$ (=1.74 $\mathrm{g} \mathrm{CDW} / \mathrm{L})$. The medium was maintained at $80{ }^{\circ} \mathrm{C}$ applying $300 \mathrm{rpm}$ agitation by magnetic stirring (STIRRING DRYBATH 15-250, 2 mag AG, Germany). $1.5 \mathrm{~mL}$ of liquid samples were taken at $1 \mathrm{~h}(\mathrm{C} 3, \mathrm{C} 4)$ and $30 \mathrm{~min}$ (C1, C2) intervals. The $\mathrm{pH}$ was manually adjusted to 7 by after each sampling. The produced gas was released continuously and quantified with $500 \mathrm{~mL}$ water displacement systems. The fermentation was completed when the gas production stopped, and the $\mathrm{pH}$ remained constant. Each experimental condition was conducted in duplicate. 


\section{Analytical methods}

Liquid samples were centrifuged at $10000 \mathrm{rpm}$ for $5 \mathrm{~min}$ to collect the supernatant for the determination of glucose, acetic acid (AA), lactic acid (LA) and alanine concentrations. The glucose concentration was measured by the dinitrosalicylic acid method calibrated on a standard solution of $1 \mathrm{~g} / \mathrm{L}$ [33]. AA, LA and alanine were quantified by ${ }^{1} \mathrm{H}$ Nuclear Magnetic Resonance (NMR) on a $600 \mathrm{MHz}$ spectrometer (Bruker Avance 400) equipped with a Cryoprobe using $3.8 \mathrm{mM}$ trimethylamine hydrochloride (TMA) as internal standard [34]. The biomass concentration was determined by measuring optical density at $540 \mathrm{~nm}\left(\mathrm{OD}_{540}\right)$ (UV/Vis spectrophotometer DU 730, Beckman Coulter Inc, Brea, USA) of the liquid samples and the CDW via lyophilization after the completion of the fermentation. For this purpose, $200 \mathrm{~mL}$ of culture broth was centrifuged at $3750 \mathrm{rpm}$ for $20 \mathrm{~min}$. The pellet was subsequently resuspended in $25 \mathrm{~mL}$ of $10 \mathrm{~g} / \mathrm{L} \mathrm{NaCl}$ in distilled water and centrifuged at $6000 \mathrm{rpm}$ for $20 \mathrm{~min}$ to remove remaining media components. The pellet was stored at $-20^{\circ} \mathrm{C}$ and lyophilized overnight.

Produced gas was quantified by water displacement using $500 \mathrm{~mL}$ glass containers. At the end of each experiment, the $\mathrm{H}_{2}$-containing gas was sampled and analyzed by gas chromatography as described by Dipasquale et al. [13]. The molar $\mathrm{H}_{2}$ production was calculated using the ideal gas law [7]. The hydrogen concentration in the produced gas was calculated considering a dilution of the measured gas with the $\mathrm{CO}_{2}$ initially in the headspace of the reactor.

\section{Kinetic study of glucose consumption, biomass growth and biohydrogen production}

To evaluate and compare glucose consumption, biomass growth and hydrogen production at the different biomass concentrations investigated, models based on the Gompertz equation $[14,35]$ were applied to fit the experimental data and calculate the kinetic rates and lag phases. To validate the suitability of the modified Gompertz model, the models of glucose consumption, biomass growth and hydrogen production were plotted against the experimental data. The quality of the fitting was determined by calculating the coefficients of determination $\left(R^{2}\right)$. The specific rates were calculated referring the volumetric rates to the initial biomass concentration of each experimental condition.

For glucose consumption, Eq. (1) was applied, where $G$ [g/L] is the glucose concentration at fermentation time $t[h] ; G_{0}[g / L]$ is the glucose concentration at time $0 \mathrm{~h} ; G_{m}[\mathrm{~g} / \mathrm{L}]$ is the glucose consumed throughout the fermentation; $R_{G}$ is the volumetric glucose consumption rate $[\mathrm{g} / \mathrm{L} / \mathrm{h}] ; \lambda_{G}$ is the lag phase of glucose consumption [h]; and $e$ is the Euler's number, i.e. 2.7183.

For biomass growth, Eq. (2) was applied, where B [g CDW/L] is the biomass concentration at fermentation time $t[h] ; B_{0}[g$ $\mathrm{CDW} / \mathrm{L}]$ is the biomass concentration at time $0 \mathrm{~h} ; \mathrm{G}_{m}$ [g CDW/L] is the gain of biomass concentration throughout the fermentation; $R_{B}$ is the volumetric growth rate [g CDW/L/h]; and $\lambda_{B}$ is the lag phase of biomass growth [h].

Eq. (3) was applied for hydrogen production, with $H[\mathrm{~mL} / \mathrm{L}]$ being the cumulative hydrogen at time $t[h] ; H_{m}[\mathrm{~mL} / \mathrm{L}]$ the hydrogen produced throughout the fermentation; $R_{H}[\mathrm{~mL} / \mathrm{L} / \mathrm{h}]$ the volumetric HPR; and $\lambda_{H}$ the lag phase of hydrogen production [h]. For the calculation of the HPR, the gas remaining in the headspace of the reactor at the end of the fermentation was equally distributed throughout the length of the batch experiment.

$$
\begin{aligned}
& G=G_{0}-G_{m} \exp \left\{-\exp \left[\frac{R_{G} e}{G_{m}}\left(\lambda_{G}-t\right)+1\right]\right\} \\
& B=B_{0}+B_{m} \exp \left\{-\exp \left[\frac{R_{B} e}{B_{m}}\left(\lambda_{B}-t\right)+1\right]\right\} \\
& H=H_{m} \exp \left\{-\exp \left[\frac{R_{H} e}{H_{m}}\left(\lambda_{H}-t\right)+1\right]\right\}
\end{aligned}
$$

\section{Results and discussion}

\section{Hydrogen yield and production rate}

A change of the initial biomass concentration between 0.46 and $1.74 \mathrm{~g} / \mathrm{L}$ did not affect the hydrogen yield i.e. $2.45( \pm 0.09)$ $\mathrm{mol} \mathrm{H}_{2} / \mathrm{mol}$ glucose (Table 1 ) or the composition of the biogas that maintained a constant level of hydrogen at $67.6( \pm 2.4) \%$ (data not shown). The HPR observed at the lowest initial biomass concentration of $0.46 \mathrm{~g}$ CDW/L (C1) reached $323( \pm 11)$ $\mathrm{mL} / \mathrm{L} / \mathrm{h}$ (Table 2). A further increment of the biomass concentration to 0.91 (C2), 1.33 (C3) and $1.74 \mathrm{~g}$ CDW/L (C4) increasingly enhanced the volumetric HPR to $448( \pm 18), 608$ $( \pm 18)$ and $654( \pm 30) \mathrm{mL} / \mathrm{L} / \mathrm{h}$ (Fig. $1 \mathrm{~B}$; Table 2), respectively. On the whole, a fourfold expansion of the biomass concentration caused an approximately twofold increase of the volumetric production rate. This is consistent with previous studies on dark fermentation by anaerobic sludge in closed serum bottles, where a general increase of HPR was obtained by raising the biomass concentrations [36,37]. On the other hand, Ngo and coworkers reported a reverse correlation between the two parameters in a fed batch process using T. neapolitana. In 4

Table 1 - Hydrogen yield, cumulative hydrogen, final biomass and biomass yield fermenting $\mathbf{5}$ g/L glucose at different initial biomass concentrations of Thermotoga neapolitana.

\begin{tabular}{cccccc} 
& $\begin{array}{c}\text { Initial biomass } \\
{[\mathrm{g} \mathrm{CDW} / \mathrm{L}]}\end{array}$ & $\begin{array}{c}\text { Hydrogen yield } \\
{[\mathrm{mol} \mathrm{H} / \mathrm{mol} \text { glucose] }}\end{array}$ & $\begin{array}{c}\text { Cumulative } \\
\text { hydrogen }[\mathrm{mL} / \mathrm{L}]\end{array}$ & $\begin{array}{c}\text { Final biomass } \\
{[\mathrm{g} \text { CDW/L] }}\end{array}$ & $\begin{array}{c}\text { Biomass yield } \\
\text { [g CDW/g glucose] }\end{array}$ \\
\hline C1 & 0.46 & 2.39 & $1462( \pm 12)$ & $1.10( \pm 0.03)$ & 0.14 \\
$\mathrm{C} 2$ & 0.91 & 2.44 & $1477( \pm 3)$ & $1.43( \pm 0.09)$ & 0.12 \\
$\mathrm{C} 3$ & 1.33 & 2.58 & $1516( \pm 10)$ & $1.89( \pm 0.06)$ & 0.13 \\
$\mathrm{C} 4$ & 1.74 & 2.37 & $1456( \pm 5)$ & $2.10( \pm 0.15)$ & 0.08 \\
\hline
\end{tabular}


Table 2 - Thermotoga neapolitana cultivated on $5 \mathrm{~g} / \mathrm{L}$ of glucose as a main substrate using different initial biomass

concentrations. Rates and lag phase determined through curve fitting to a modified Gompertz model. Fit quality illustrated through coefficient of determination $\left(\mathbf{R}^{2}\right)$.

\begin{tabular}{|c|c|c|c|c|c|}
\hline & itial biomass & Volumetric rate & Specific rate & Lag phase & $\mathrm{R}^{2}$ \\
\hline \multicolumn{6}{|c|}{ Hydrogen production } \\
\hline & [g CDW/L] & {$[\mathrm{mL} / \mathrm{L} / \mathrm{h}]$} & {$[\mathrm{mL} / \mathrm{h} / \mathrm{g}$ initial CDW] } & {$[\mathrm{h}]$} & \\
\hline $\mathrm{C} 1$ & 0.46 & $323( \pm 11)$ & $699( \pm 23)$ & $1.50( \pm 0.07)$ & 0.99 \\
\hline $\mathrm{C} 2$ & 0.91 & $448( \pm 18)$ & $494( \pm 20)$ & $0.79( \pm 0.01)$ & 0.99 \\
\hline C3 & 1.33 & $608( \pm 18)$ & $456( \pm 13)$ & $0.52( \pm 0.01)$ & 0.99 \\
\hline $\mathrm{C} 4$ & 1.74 & $654( \pm 30)$ & $375( \pm 17)$ & $0.40( \pm 0.02)$ & 0.99 \\
\hline \multicolumn{6}{|c|}{ Biomass growth } \\
\hline & [g CDW/L] & [mg CDW/L/h] & [mg CDW/h/g initial CDW] & & \\
\hline $\mathrm{C} 1$ & 0.46 & $190( \pm 0)$ & $412( \pm 0)$ & & 0.99 \\
\hline C2 & 0.91 & $230( \pm 0)$ & $254( \pm 0)$ & & 0.98 \\
\hline C3 & 1.33 & $320( \pm 0)$ & $240( \pm 0)$ & & 0.96 \\
\hline $\mathrm{C} 4$ & 1.74 & $400( \pm 28)$ & $229( \pm 16)$ & & 0.98 \\
\hline \multicolumn{6}{|c|}{ Glucose consumption } \\
\hline & [g CDW/L] & [g Glucose/L/h] & [g Glucose/h/g initial CDW] & & \\
\hline $\mathrm{C} 1$ & 0.46 & $1.08( \pm 0.04)$ & $2.33( \pm 0.08)$ & & 0.99 \\
\hline $\mathrm{C} 2$ & 0.91 & $1.40( \pm 0.00)$ & $1.55( \pm 0.00)$ & & 0.98 \\
\hline C3 & 1.33 & $1.98( \pm 0.04)$ & $1.48( \pm 0.03)$ & & 0.98 \\
\hline $\mathrm{C} 4$ & 1.74 & $2.35( \pm 0.07)$ & $1.35( \pm 0.04)$ & & 0.99 \\
\hline
\end{tabular}

feeding cycles, the authors observed an increase of the initial biomass from $1.3 \pm 0.1$ to $2.4 \pm 0.1 \mathrm{~g} / \mathrm{L}$ yielding a mild reduction of HPR from 114 to $106 \mathrm{~mL} / \mathrm{L} / \mathrm{h}$ [32]. Simultaneously, acetic acid and lactic acid accumulated in the fermentation broth up to $123 \pm 7$ and $28 \pm 1 \mathrm{mM}$, respectively, which could potentially have caused an inhibitory effect.

While hyperthermophilic cultures are capable to achieve even higher hydrogen yields (Table 3) the volumetric HPR observed in this work exceeds those achieved in similar studies using pure hyperthermophilic cultures at low biomass concentrations (Table 3).

The highest production rate of $654( \pm 30) \mathrm{mL} / \mathrm{L} / \mathrm{h}(\mathrm{C} 4)$ (Table 2) depicts a roughly 13 -fold increase to the maximum production rate of $50 \mathrm{~mL} / \mathrm{L} / \mathrm{h}$ achieved in similar experiments using Thermotoga neapolitana in batch cultures with $6 \%(\mathrm{v} / \mathrm{v})$ of inoculum and $5 \mathrm{~g} / \mathrm{L}$ of glucose as a substrate [19]. Only two studies achieved HPRs in a similar range. Mars et al. [31] and de Vrije et al. [11] reached production rates of 269 and $304 \mathrm{~mL} /$ $\mathrm{L} / \mathrm{h}$, respectively, by continuously flushing the reactor headspace with $\mathrm{N}_{2}$ gas at $7 \mathrm{~L} / \mathrm{h}$ both using $10 \%(\mathrm{v} / \mathrm{v})$ of preculture as inoculum and $10 \mathrm{~g}$ glucose/L as a substrate. While gas sparging is a common method to counteract hydrogen inhibition $[25,44]$, it is an unsatisfying solution due to a manifold dilution of the produced hydrogen gas. The resulting need to separate the sparging gas from the hydrogen creates additional operating cost [45].
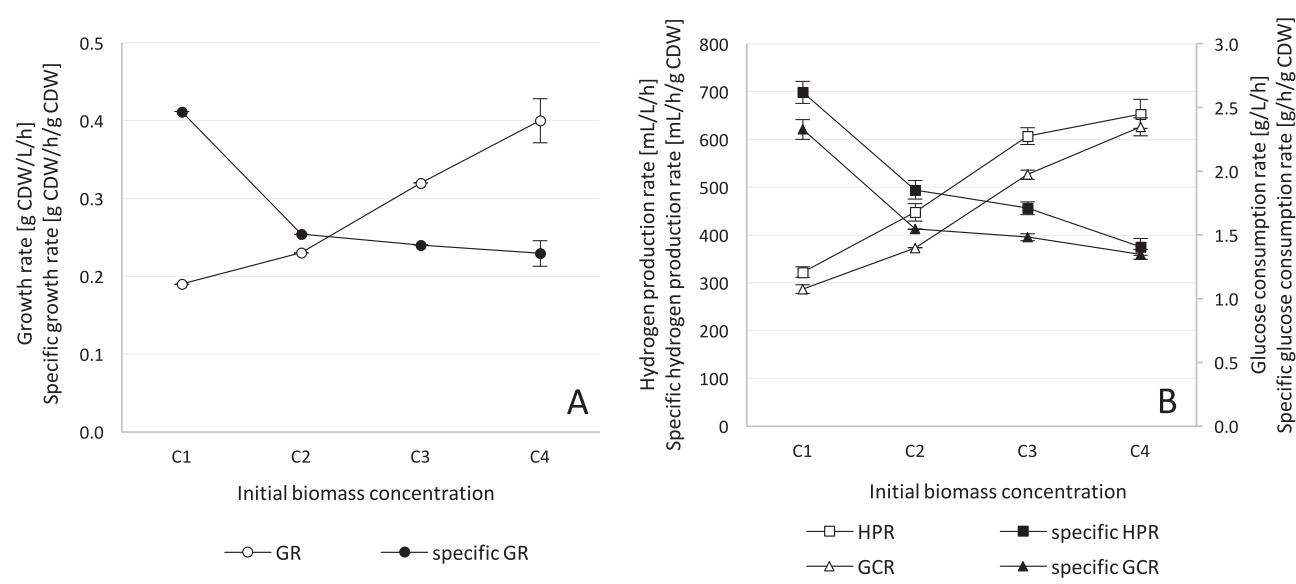

Fig. 1 - A - Volumetric and specific growth rate; B - Volumetric as well as specific glucose consumption and hydrogen production rate at different initial biomass concentrations $(\mathrm{C} 1=0.46 ; \mathrm{C} 2=0.91 ; \mathrm{C} 3=1.33 ; \mathrm{C4}=1.74 \mathrm{~g} \mathrm{CDW} / \mathrm{L})$ of $\mathrm{Thermotoga}$ neapolitana fermenting $5 \mathrm{~g} / \mathrm{L}$ of glucose. Specific rates were calculated per $\mathrm{g}$ initial cell dry weight. (GR - Growth rate; HPR Hydrogen production rate; GCR - Glucose consumption rate). 
Table 3 - Hydrogen production rate and hydrogen yield of selected studies of batch fermentations by various hyperthermophilic pure cultures using glucose as a substrate.

\begin{tabular}{|c|c|c|c|}
\hline Microorganism & $\begin{array}{l}\text { Hydrogen production } \\
\text { rate }[\mathrm{mL} / \mathrm{L} / \mathrm{h}]\end{array}$ & $\begin{array}{c}\text { Hydrogen yield } \\
\text { [mol } \mathrm{H}_{2} / \mathrm{mol} \text { glucose] }\end{array}$ & Reference \\
\hline \multirow[t]{3}{*}{ Caldicellulosiruptor saccharolyticus } & 264 & 2.5 & [38] \\
\hline & 296 & 3.4 & [31] \\
\hline & 277 & 3.2 & [11] \\
\hline Thermotoga elfi & 200 & 3.3 & [39] \\
\hline Thermotoga maritima & 170 & 4 & {$[40]$} \\
\hline \multirow[t]{5}{*}{ Thermotoga neapolitana } & 304 & 2.9 & [31] \\
\hline & 269 & 3.5 & [11] \\
\hline & 21 & 3.9 & [18] \\
\hline & 252 & 1.8 & [20] \\
\hline & 50 & 3.9 & [19] \\
\hline Thermoanaerobacter mathranii A3N & 100 & 2.6 & [41] \\
\hline Thermoanaerobacterium thermosaccharolyticum PSU-2 & 287 & 2.4 & [42] \\
\hline Thermoanaerobacterium thermosaccharolyticum W16 & 309 & 2.4 & [43] \\
\hline Thermotoga neapolitana & 654 & 2.5 & Present study \\
\hline
\end{tabular}

Volumetric and specific rates of glucose consumption, biomass growth and hydrogen production

Volumetric (per L of working volume) and specific (per g CDW) glucose consumption, biomass growth and HPRs (Fig. 1, Table 2) were calculated via the Gompertz model (described in 2.6) (Fig. 2). The increase of the volumetric HPR with increasing biomass concentrations was coupled to a general acceleration of the process, indicated by an increase of the volumetric biomass growth and glucose consumption rate (Table 2). The calculation of the Pearson correlation coefficient, confirmed a positive linear correlation of volumetric glucose consumption rate and volumetric growth rate $(r=0.99)$ as well as volumetric HPR $(r=0.99)$. In contrast, all specific rates (Fig. 1, Table 2) exhibited a decreasing trend with increasing biomass concentrations. This suggests that the overall process was considerably accelerated, while the individual cells were partially repressed at increased biomass concentration. The decrease in specific rates was particularly distinct between $\mathrm{C} 1$ and C2. The specific glucose consumption rate (g glucose/h/g CDW) dropped by $34 \%$ from $2.33( \pm 0.08)$ of C1 to $1.55( \pm 0)$ of C2 and by $9 \%$ to $1.35( \pm 0.04)$ of $\mathrm{C} 4$ (Table 2$)$. The specific growth rate $(\mathrm{mg} \mathrm{CDW} / \mathrm{h} / \mathrm{g} \mathrm{CDW})$ decreased by $38 \%$ from $412( \pm 0)$ of $\mathrm{C} 1$ to $254( \pm 0)$ of C2 and merely by $6 \%-229( \pm 16)$ of C4 (Table 2). The specific HPR (mL/h/g CDW) decreased by $29 \%$ from 699 ( \pm 23 ) of C1 to $494( \pm 20)$ of C2 and by $17 \%-375( \pm 17)$ of C4 (Table 2). A similar trend of decreasing specific HPR was observed in previous studies when the initial biomass was increased using mixed cultures [36,37]. Kargi et al. [37] observed a drop of the specific HPR from 48 to approximately $3 \mathrm{~mL} / \mathrm{h} / \mathrm{g}$ when the biomass concentration was increased from 0.48 to $2.88 \mathrm{~g} / \mathrm{L}$. Substrate limitation caused by flock formation [37] and hydrogen consuming homo-acetogenic bacteria [36] were presumed to be responsible for the decrease of specific HPR at higher initial biomass concentrations.

In the present study, the formation of flocks was not hydrogen was not consumed, indicated by the ratio of hydrogen to acetic acid being consistent with the dark fermentation model (Eq. (4)). However, an increase of HPR induces the accumulation of hydrogen in the liquid phase which mainly depends on the HPR and the mass transfer rate of system [46]. The concentration of liquid phase hydrogen can reach multiple fold the equilibrium concentration suggested by Henry's Law even in hyperthermophilic stirred reactor systems [46,47], acting as a potent inhibitor of hydrogen production by dark fermentation [44,48]. In the present study, the accumulation of hydrogen was observed at the highest biomass concentration (C4) where the highest HPR was obtained. After $3 \mathrm{~h}$ of fermentation, the glucose consumption of C4 was completed (Fig. 2C), while hydrogen continued to be produced by the reactor (Fig. 2B), due to the transport of accumulated hydrogen from the liquid to the gas phase. According to Ljunggren et al. [46], cultures of Caldicellulosiruptor saccharolyticus respond to increasing concentrations of liquid phase hydrogen by adjusting the specific growth rate to reduce the HPR and prevent hydrogen from reaching inhibitory concentrations. Similarly, a reduction of specific HPRs was observed in the presented study when the volumetric production rates increased. This is supported by the results obtained in dark fermentation by Thermotoga neapolitana, achieving the highest hydrogen yields and production rates, when hydrogen was removed through headspace sparging with $\mathrm{N}_{2}$ continuously [11,31] or in regular intervals [19].

\section{Fermentation time and lag phase}

The lag phase was determined via the Gompertz model, while the fermentation time was estimated from the moment of inoculation to the completion of the fermentation. An initial biomass concentration of $0.46 \mathrm{~g}$ CDW/L (C1) induced a lag phase of $1.50( \pm 0.07) \mathrm{h}$ (Table 2$)$ and the completion of the fermentation within approximately $7 \mathrm{~h}$ (Fig. 2). In previous studies, the duration of the batch fermentation with Thermotoga neapolitana was longer than $18 \mathrm{~h}[11,23,31]$ when applying a $5-10 \%(v / v)$ inoculum. By increasing the initial biomass concentration to $1.74 \mathrm{~g} \mathrm{CDW/L}(\mathrm{C} 4)$, the fermentation time and the lag phase were reduced to approximately $3 \mathrm{~h}$ (Figs. 2) and $0.4( \pm 0.02) \mathrm{h}$ (Table 2), respectively. This is in agreement with observations made in bioethanol production plants [28], 

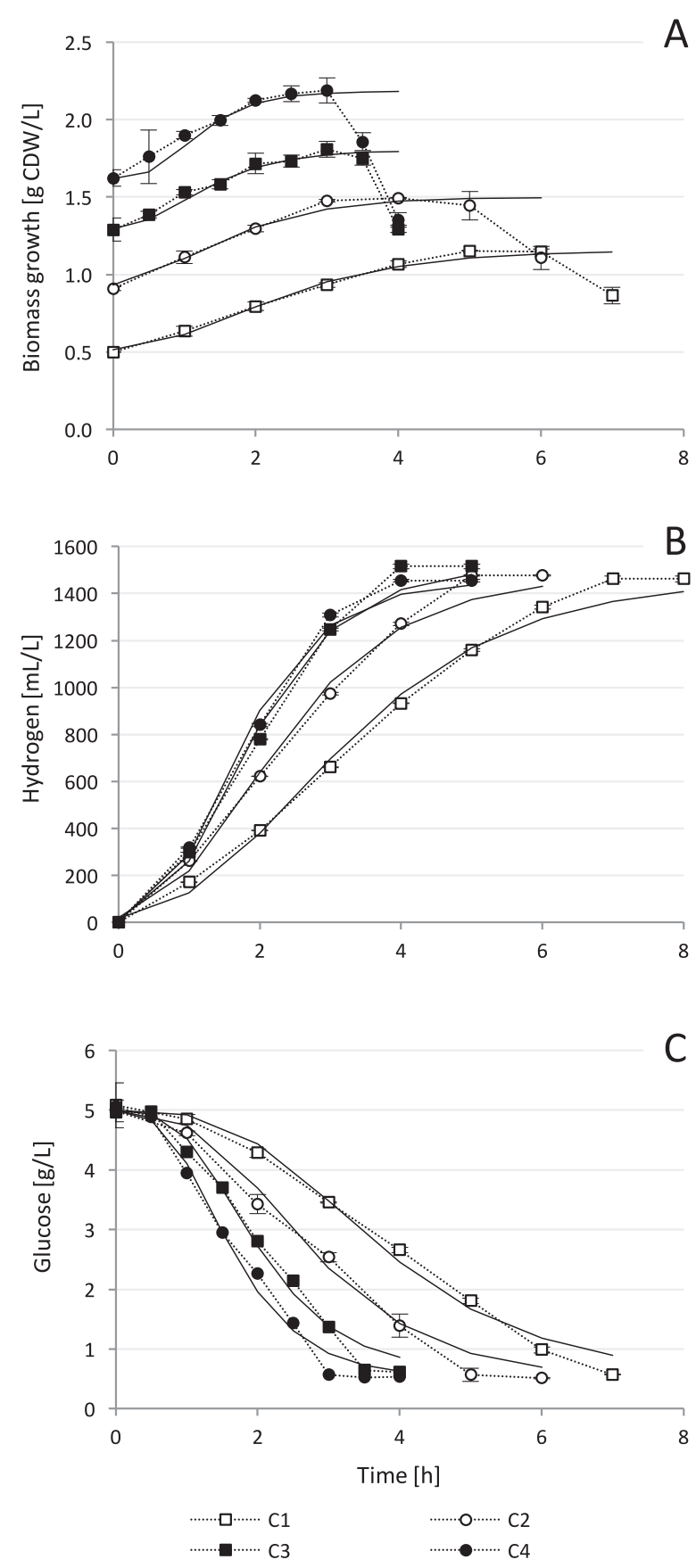

Fig. 2 - A - Biomass growth; B - Cumulative hydrogen and C - Glucose consumption production at different initial biomass concentrations $(\mathrm{C} 1=0.46 ; \mathrm{C} 2=0.91 ; \mathrm{C} 3=1.33$; C4 $=1.74 \mathrm{~g} \mathrm{CDW} / \mathrm{L}$ ) of Thermotoga neapolitana fermenting $5 \mathrm{~g} / \mathrm{L}$ of glucose. The solid line represents the fitting to the Gompertz model.

where yeast cultures were recycled at high densities in sequential batch fermentations resulting in the reduction of the fermentation time and the unproductive lag phase [27]. In all conditions, independent from the initial biomass concentration a substrate consumption of $88.8( \pm 0.9) \%$ (data not shown) was reached at the end of the fermentation.

\section{Biomass production}

The biomass concentration at the end of a batch fermentation is defined by the initial biomass concentration, the biomass yield (g CDW/g glucose) and the amount of glucose converted. A similar formation of biomass was observed using initial biomass concentrations between 0.46 (C1) and 1.33 (C3), with a biomass yield ranging between 0.12 and $0.14 \mathrm{~g}$ CDW/g glucose (Table 1). In contrast, at the highest biomass concentration of $1.74 \mathrm{~g} \mathrm{CDW} / \mathrm{L}$ (C4) the biomass production was lower, corresponding to a biomass yield of $0.08 \mathrm{~g} \mathrm{CDW} / \mathrm{g}$ glucose (Table 1), similar to what observed in previous studies with lower inoculum concentrations of Thermotoga neapolitana. De Vrije et al. [11] and Mars et al. [31] reported biomass yields of 81.6 and $87.1 \mathrm{mg}$ CDW/g glucose, respectively, using $10 \%$ inoculum (v/v) with additional headspace sparging. Ngo et al. [23] obtained $0.71( \pm 0.04) \mathrm{g} C D W / \mathrm{L}$ with $10 \mathrm{~g} / \mathrm{L}$ pure glycerol as main substrate and $10 \%$ of inoculum (v/v). Van Niel et al. [39] reached $0.89 \mathrm{~g}$ CDW/L by fermenting $10 \mathrm{~g} / \mathrm{L}$ glucose with $10 \%$ inoculum of Thermotoga elfi. At the end of each fermentation Thermotoga neapolitana is morphologically adapting to the nutrient limitation causing the $\mathrm{OD}_{540}$ to decrease (Fig. 2) [49], while the CDW remains high (Table 1). Consequently, the curve fitting to the Gompertz model for biomass growth was done exclusively until the highest value of turbidity was reached (Fig. 2).

\section{Production of fermentation products}

The distribution of end products obtained in the digestate (62.3 $( \pm 2.5) \%$ AA; $23.5( \pm 2.9) \%$ LA; $2.3( \pm 0.1) \%$ alanine) was similar in the range of biomass concentrations investigated (Table 4), corresponding to yields of $1.33( \pm 0.05) \mathrm{mol} / \mathrm{mol}$ glucose for AA, $0.50( \pm 0.06) \mathrm{mol} / \mathrm{mol}$ glucose for LA and 0.05 $( \pm 0.001) \mathrm{mol} / \mathrm{mol}$ glucose for alanine (Table 4$)$. As observed in previous studies [14], Thermotoga neapolitana primarily ferments glucose via the hydrogen producing acetic acid (Eq. (4)) or the lactic acid pathway (Eq. (5)).

$$
\begin{aligned}
& \mathrm{C}_{6} \mathrm{H}_{12} \mathrm{O}_{6}+4 \mathrm{ADP}+4 \mathrm{H}_{2} \mathrm{PO}_{4}^{-} \leftrightarrow 2 \mathrm{CH}_{3} \mathrm{CO}_{2} \mathrm{H}+2 \mathrm{CO}_{2}+4 \mathrm{ATP}+4 \mathrm{H}_{2} \\
& \quad+2 \mathrm{H}_{2} \mathrm{O}
\end{aligned}
$$

$\mathrm{C}_{6} \mathrm{H}_{12} \mathrm{O}_{6}+2 \mathrm{ADP}+2 \mathrm{H}_{2} \mathrm{PO}_{4}^{-} \leftrightarrow 2 \mathrm{CH}_{3} \mathrm{CH}(\mathrm{OH}) \mathrm{CO}_{2} \mathrm{H}+2 \mathrm{ATP}+2 \mathrm{H}_{2} \mathrm{O}$

Considering a production of $2 \mathrm{~mol}$ of end product per mol of glucose (Eqs. (4) and (5)), an average of $95( \pm 1) \%$ (data not shown) of the initial substrate could be accounted for in the fermentation broth (Table 4). Similar results were obtained by Mars et al. [31] and de Vrije et al. [11] when low inoculum concentrations were used, reporting AA yields of 1.6 and $1.4 \mathrm{~mol} / \mathrm{mol}$ glucose and LA yields of $<0.1$ and $0.03 \mathrm{~mol} / \mathrm{mol}$ glucose, respectively. The highest initial biomass concentration (C4) showed a slightly higher LA/AA ratio (Table 4) coupled with a slightly lower hydrogen yield (Table 1). This is in accordance to the dark fermentation model suggesting a negative correlation between hydrogen yield and LA/AA ratio [48].

Additionally, an impact of capnophilic lactic acid fermentation caused by sparging with $\mathrm{CO}_{2}$ needs to be considered 
Table 4 - Composition of broth after completed fermentation of $5 \mathrm{~g} / \mathrm{L}$ glucose by different initial biomass concentrations (C1 = 0.46; C2 = 0.91; C3 = 1.33; C4 = 1.74 g cell dry weight/L) of Thermotoga neapolitana.

\begin{tabular}{|c|c|c|c|c|c|}
\hline & $\begin{array}{c}\mathrm{AA}[\mathrm{mM}] \\
\text { \{yield }[\mathrm{mol} / \mathrm{mol} \text { glu] }\end{array}$ & $\begin{array}{c}\text { LA [mM] } \\
\{\text { yield [mol/mol glu]\} }\end{array}$ & Ratio LA/AA & $\begin{array}{c}\text { Alanine }[\mu \mathrm{M}] \\
\{\text { yield }[\mathrm{mol} / \mathrm{mol} \text { glu }]\}\end{array}$ & Glucose [mM] \\
\hline C1 & $34.3( \pm 0.6)\{1.39\}$ & $10.9( \pm 0.4)\{0.44\}$ & 0.32 & $1190( \pm 27)\{0.05\}$ & $3.2( \pm 0.04)$ \\
\hline C2 & $32.9( \pm 0.8)\{1.32\}$ & $12.2( \pm 0.8)\{0.49\}$ & 0.37 & $1260( \pm 1)\{0.05\}$ & $2.9( \pm 0.06)$ \\
\hline C3 & $32.3( \pm 0.2)\{1.33\}$ & $11.5( \pm 0.5)\{0.47\}$ & 0.36 & $1220( \pm 18)\{0.05\}$ & $3.4( \pm 0.01)$ \\
\hline C4 & $31.4( \pm 1.1)\{1.27\}$ & $14.7( \pm 0.7)\{0.59\}$ & 0.47 & $1260( \pm 43)\{0.05\}$ & $3.0( \pm 0.04)$ \\
\hline
\end{tabular}

resulting in elevated amounts of LA without significant loss in hydrogen yield [30,34]. Dipasquale et al. [30] observed LA/AA ratio of 0.28 by $\mathrm{N}_{2}$ sparging and 0.56 by $\mathrm{CO}_{2}$ sparging twice throughout the batch experiment. LA/AA ratios between 0.32 and 0.47 observed in this study suggest a similar influence of capnophilic lactic acid fermentation.

\section{Conclusion}

This study identified the use of high initial biomass concentrations of Thermotoga neapolitana (from 0.46 to 1.74 g cell dry weight/L) as a suitable method to accelerate the dark fermentation process and increase the HPR. The four-fold increase in biomass concentration led to the consumption of $5 \mathrm{~g} / \mathrm{L}$ of glucose within $3 \mathrm{~h}$ and accelerated the hydrogen production rate by approximately 50\% reaching a maximum of $654( \pm 30) \mathrm{mL} / \mathrm{L} / \mathrm{h}$. The variation of the biomass concentration had no effect on the yield $\left(2.45( \pm 0.09) \mathrm{mol} \mathrm{H}_{2} / \mathrm{mol}\right.$ glucose), the concentration of hydrogen in the produced gas $(68 \%)$ or the composition of fermentation end products (i.e. $62.3( \pm 2.5) \%$ AA, $23.5( \pm 2.9) \%$ LA and $2.3( \pm 0.1) \%$ alanine). To continue optimizing the rate of dark fermentation processes more research is required to understand the role of hydrogen in the liquid phase as an inhibitor at elevated hydrogen production rates. Furthermore, economical and environmentally friendly substrates like organic waste streams need to be investigated for their suitability in large-scale applications of the proposed process.

\section{Acknowledgements}

This work was supported by the Marie Skłodowska-Curie European Joint Doctorate (EJD) in Advanced Biological Waste-ToEnergy Technologies (ABWET) funded from Horizon 2020 under grant agreement no. 643071. Angelo Fontana and Giuliana d'Ippolito thank the support from the EU Horizon 2020 Research and Innovation Program under the Grant Agreement No. 760431 (BioRECO2VER). The authors also express their appreciation to the staff of CNR-ICB for the consistent help throughout this study.

\section{R E F E R E N C E S}

[1] Gupta SK, Kumari S, Reddy K, Bux F. Trends in biohydrogen production: major challenges and state-of-the-art developments. Environ Technol 2013;34(13-16):1653-70. https://doi.org/10.1080/09593330.2013.822022.

[2] Elsharnouby O, Hafez H, Nakhla G, El Naggar MH. A critical literature review on biohydrogen production by pure cultures. Int J Hydrogen Energy 2013;38(12):4945-66. https:// doi.org/10.1016/j.ijhydene.2013.02.032.

[3] Yasin NHM, Mumtaz T, Hassan MA, Abd Rahman N. Food waste and food processing waste for biohydrogen production: a review. J Environ Manag 2013;130:375-85. https://doi.org/10.1016/j.jenvman.2013.09.009.

[4] Balachandar G, Khanna N, Das D. Biohydrogen production from organic wastes by dark fermentation. In: Biohydrogen. Elsevier; 2013. p. 103-44. https://doi.org/10.1016/B978-0-44459555-3.00006-4.

[5] Lee D-J, Show K-Y, Su A. Dark fermentation on biohydrogen production: pure culture. Bioresour Technol 2011;102(18): 8393-402. https://doi.org/10.1016/j.biortech.2011.03.041.

[6] Show KY, Lee DJ, Tay JH, Lin CY, Chang JS. Biohydrogen production: current perspectives and the way forward. Int $J$ Hydrogen Energy 2012;37(20):15616-31. https://doi.org/ 10.1016/j.ijhydene.2012.04.109.

[7] O-Thong S, Prasertsan P, Karakashev D, Angelidaki I. Highrate continuous hydrogen production by Thermoanaerobacterium thermosaccharolyticum PSU-2 immobilized on heat-pretreated methanogenic granules. Int J Hydrogen Energy 2008;33(22):6498-508. https://doi.org/ 10.1016/j.ijhydene.2008.07.060.

[8] Argun H, Kargi F, Kapdan IK. Effects of the substrate and cell concentration on bio-hydrogen production from ground wheat by combined dark and photo-fermentation. Int J Hydrogen Energy 2009;34(15):6181-8. https://doi.org/10.1016/ j.ijhydene.2009.05.130.

[9] Davila-Vazquez G, Cota-Navarro CB, Rosales-Colunga LM, de León-Rodríguez A, Razo-Flores E. Continuous biohydrogen production using cheese whey: improving the hydrogen production rate. Int J Hydrogen Energy 2009;34(10):4296-304. https://doi.org/10.1016/j.ijhydene.2009.02.063.

[10] Pawar SS, van Niel EWJ. Thermophilic biohydrogen production: how far are we? Appl Microbiol Biotechnol 2013;97(18):7999-8009. https://doi.org/10.1007/s00253-0135141-1.

[11] de Vrije T, Budde MA, Lips SJ, Bakker RR, Mars AE, Claassen PA. Hydrogen production from carrot pulp by the extreme thermophiles Caldicellulosiruptor saccharolyticus and Thermotoga neapolitana. Int J Hydrogen Energy 2010;35(24):13206-13. https://doi.org/10.1016/j.ijhydene.2010. 09.014.

[12] Cappelletti M, Bucchi G, de Sousa Mendes J, Alberini A, Fedi S, Bertin L, et al. Biohydrogen production from glucose, molasses and cheese whey by suspended and attached cells of four hyperthermophilic Thermotoga strains. J Chem Technol Biotechnol 2012;87(9):1291-301. https://doi.org/ 10.1002/jctb.3782.

[13] Dipasquale L, d'Ippolito G, Gallo C, Vella FM, Gambacorta A, Picariello G, et al. Hydrogen production by the thermophilic 
eubacterium Thermotoga neapolitana from storage polysaccharides of the $\mathrm{CO}_{2}$-fixing diatom Thalassiosira weissflogii. Int J Hydrogen Energy 2012;37(17):12250-7. https:// doi.org/10.1016/j.ijhydene.2012.05.160.

[14] Pradhan N, Dipasquale L, d'Ippolito G, Panico A, Lens PNL, Esposito G, et al. Hydrogen production by the thermophilic bacterium Thermotoga neapolitana. Int J Mol Sci 2015;16(6):12578-600. https://doi.org/10.3390/ijms160612578.

[15] Huber R, Hannig M. Thermotogales. In: Dworkin M, Falkow S, Rosenberg E, Schleifer K-H, Stackebrandt E, editors. The prokaryotes. New York, NY: Springer New York; 2006. p. 899-922. https://doi.org/10.1007/0-387-30747-8_38.

[16] Pradhan N, Dipasquale L, d'Ippolito G, Fontana A, Panico A, Lens $\mathrm{PN}$, et al. Kinetic modeling of fermentative hydrogen production by Thermotoga neapolitana. Int J Hydrogen Energy 2016;41(9):4931-40. https://doi.org/10.1016/j.ijhydene. 2016.01.107.

[17] Nguyen T-AD, Han SJ, Kim JP, Kim MS, Sim SJ. Hydrogen production of the hyperthermophilic eubacterium, Thermotoga neapolitana under $\mathrm{N}_{2}$ sparging condition. Bioresour Technol 2010;101(Suppl. 1):41. https://doi.org/ 10.1016/j.biortech.2009.03.041.

[18] Munro SA, Zinder SH, Walker LP. The fermentation stoichiometry of Thermotoga neapolitana and influence of temperature, oxygen, and $\mathrm{pH}$ on hydrogen production. Biotechnol Prog 2009;25(4):1035-42. https://doi.org/10.1002/ btpr.201.

[19] d'Ippolito G, Dipasquale L, Vella FM, Romano I, Gambacorta A, Cutignano A, et al. Hydrogen metabolism in the extreme thermophile Thermotoga neapolitana. Int $\mathrm{J}$ Hydrogen Energy 2010;35(6):2290-5. https://doi.org/10.1016/ j.ijhydene.2009.12.044.

[20] Nguyen T-AD, Kim JP, Kim MS, Oh YK, Sim SJ. Optimization of hydrogen production by hyperthermophilic eubacteria, Thermotoga maritima and Thermotoga neapolitana in batch fermentation. Int J Hydrogen Energy 2008;33(5):1483-8. https://doi.org/10.1016/j.ijhydene.2007.09.033.

[21] Thauer RK, Jungermann K, Decker K. Energy conservation in chemotrophic anaerobic bacteria. Bacteriol Rev 1977;41(1):100-80.

[22] Basile MA, Carfagna C, Cerruti P, Gomez d'Ayala G, Fontana A, Gambacorta A, et al. Continuous hydrogen production by immobilized cultures of Thermotoga neapolitana on an acrylic hydrogel with pH-buffering properties. RSC Adv 2012;2(9):3611. https://doi.org/10.1039/ c2ra01025a.

[23] Ngo TA, Bui HTV. Biohydrogen production using immobilized cells of hyperthermophilic eubacterium Thermotoga neapolitana on porous glass beads. J Technol Innovat Renew Energy 2013:231-8.

[24] Frascari D, Cappelletti M, Mendes JDS, Alberini A, Scimonelli F, Manfreda C, et al. A kinetic study of biohydrogen production from glucose, molasses and cheese whey by suspended and attached cells of Thermotoga neapolitana. Bioresour Technol 2013;147:553-61. https:// doi.org/10.1016/j.biortech.2013.08.047.

[25] Gupta N, Pal M, Sachdeva M, Yadav M, Tiwari A. Thermophilic biohydrogen production for commercial application: the whole picture. Int J Energy Res 2016;40(2):127-45. https://doi.org/10.1002/er.3438.

[26] Chou C-J, Jenney FEJR, Adams MWW, Kelly RM. Hydrogenesis in hyperthermophilic microorganisms: implications for biofuels. Metab Eng 2008;10(6):394-404. https://doi.org/ 10.1016/j.ymben.2008.06.007.

[27] Westman JO, Franzen CJ. Current progress in high cell density yeast bioprocesses for bioethanol production. Biotechnol J 2015;10(8):1185-95. https://doi.org/10.1002/ biot.201400581.
[28] Basso CL, Basso OT, Rocha NS. Ethanol production in Brazil: the industrial process and its impact on yeast fermentation. In: Dos Santos Bernardes MA, editor. Biofuel productionrecent developments and prospects. InTech; 2011. p. 85-100. https://doi.org/10.5772/17047.

[29] Pradhan N, Dipasquale L, d'Ippolito G, Panico A, Lens PN, Esposito G, et al. Hydrogen and lactic acid synthesis by the wild-type and a laboratory strain of the hyperthermophilic bacterium Thermotoga neapolitana DSMZ $4359 \mathrm{~T}$ under capnophilic lactic fermentation conditions. Int J Hydrogen Energy 2017;42(25):16023-30. https://doi.org/10.1016/ j.ijhydene.2017.05.052.

[30] Dipasquale L, d'Ippolito G, Fontana A. Capnophilic lactic fermentation and hydrogen synthesis by Thermotoga neapolitana: an unexpected deviation from the dark fermentation model. Int J Hydrogen Energy 2014;39(10):4857-62. https://doi.org/10.1016/j.ijhydene. 2013.12.183.

[31] Mars AE, Veuskens T, Budde MA, van Doeveren PF, Lips SJ, Bakker RR, et al. Biohydrogen production from untreated and hydrolyzed potato steam peels by the extreme thermophiles Caldicellulosiruptor saccharolyticus and Thermotoga neapolitana. Int J Hydrogen Energy 2010;35(15):7730-7. https://doi.org/ 10.1016/j.ijhydene.2010.05.063.

[32] Ngo TA, Kim M-S, Sim SJ. Thermophilic hydrogen fermentation using Thermotoga neapolitana DSM 4359 by fedbatch culture. Int J Hydrogen Energy 2011;36(21):14014-23. https://doi.org/10.1016/j.ijhydene.2011.04.058.

[33] Bernfeld P. Amylases, $\alpha$ and $\beta$. In: Chance B, editor. Preparation and assay of enzymes. San Diego, Calif: Acad. Press; 1955. p. 149-58.

[34] d'Ippolito G, Dipasquale L, Fontana A. Recycling of carbon dioxide and acetate as lactic acid by the hydrogen-producing bacterium Thermotoga neapolitana. ChemSusChem 2014;7(9):2678-83. https://doi.org/10.1002/cssc.201402155.

[35] Lay J-J, Li Y-Y, Noike T. Influences of $\mathrm{pH}$ and moisture content on the methane production in high-solids sludge digestion. Water Res 1997;31(6):1518-24. https://doi.org/ 10.1016/S0043-1354(96)00413-7.

[36] Argun H, Kargi F, Kapdan I, Oztekin R. Batch dark fermentation of powdered wheat starch to hydrogen gas: effects of the initial substrate and biomass concentrations. Int J Hydrogen Energy 2008;33(21):6109-15. https://doi.org/ 10.1016/j.ijhydene.2008.08.004.

[37] Kargi F, Eren NS, Ozmihci S. Effect of initial bacteria concentration on hydrogen gas production from cheese whey powder solution by thermophilic dark fermentation. Biotechnol Prog 2012;28(4):931-6. https://doi.org/10.1002/ btpr.1558.

[38] Kádár Z, de Vrije T, van Noorden GE, Budde MAW, Szengyel Z, Réczey K, et al. Yields from glucose, xylose, and paper sludge hydrolysate during hydrogen production by the extreme thermophile Caldicellulosiruptor saccharolyticus. ABAB 2004;114(1-3):497-508. https://doi.org/10.1385/ABAB:114:13:497.

[39] van Niel EWJ, Budde MAW, de Haas GG, van der Wal FJ, Claassen PAM, Stams AJM. Distinctive properties of high hydrogen producing extreme thermophiles, Caldicellulosiruptor saccharolyticus and Thermotoga elfii. Int J Hydrogen Energy 2002;27:1391-8.

[40] Schröder C, Selig M, Schönheit P. Glucose fermentation to acetate, $\mathrm{CO} 2$ and $\mathrm{H} 2$ in the anaerobic hyperthermophilic eubacterium Thermotoga maritima: involvement of the Embden-Meyerhof pathway. Arch Microbiol 1994;161(6):460-70. https://doi.org/10.1007/BF00307766.

[41] Jayasinghearachchi HS, Sarma PM, Lal B. Biological hydrogen production by extremely thermophilic novel bacterium Thermoanaerobacter mathranii A3N isolated from oil producing 
well. Int J Hydrogen Energy 2012;37(7):5569-78. https:// doi.org/10.1016/j.ijhydene.2011.12.145.

[42] O-Thong S, Prasertsan P, Karakashev D, Angelidaki I. Thermophilic fermentative hydrogen production by the newly isolated Thermoanaerobacterium thermosaccharolyticum PSU-2. Int J Hydrogen Energy 2008;33(4):1204-14. https:// doi.org/10.1016/j.ijhydene.2007.12.015.

[43] Ren N, Cao G, Wang A, Lee D, Guo W, Zhu Y. Dark fermentation of xylose and glucose mix using isolated Thermoanaerobacterium thermosaccharolyticum W16. Int J Hydrogen Energy 2008;33(21):6124-32. https://doi.org/ 10.1016/j.ijhydene.2008.07.107.

[44] Beckers L, Masset J, Hamilton C, Delvigne F, Toye D, Crine M, et al. Investigation of the links between mass transfer conditions, dissolved hydrogen concentration and biohydrogen production by the pure strain Clostridium butyricum CWBI1009. Biochem Eng J 2015;98:18-28. https:// doi.org/10.1016/j.bej.2015.01.008.

[45] Sonnleitner A, Peintner C, Wukovits W, Friedl A, Schnitzhofer W. Process investigations of extreme thermophilic fermentations for hydrogen production: effect of bubble induction and reduced pressure. Bioresour Technol 2012;118:170-6. https://doi.org/10.1016/ j.biortech.2012.05.046.

[46] Ljunggren M, Willquist K, Zacchi G, Van Niel EWJ. A kinetic model for quantitative evaluation of the effect of hydrogen and osmolarity on hydrogen production by Caldicellulosiruptor saccharolyticus. Biotechnol Biofuels 2011;4(1):31. https:// doi.org/10.1186/1754-6834-4-31.

[47] Zhang Y, Zhang F, Chen M, Chu P-N, Ding J, Zeng RJ. Hydrogen supersaturation in extreme-thermophilic $\left(70^{\circ} \mathrm{C}\right)$ mixed culture fermentation. Appl Energy 2013;109:213-9. https://doi.org/10.1016/j.apenergy.2013.04.019.

[48] Verhaart MRA, Bielen AAM, van der Oost J, Stams AJM, Kengen SWM. Hydrogen production by hyperthermophilic and extremely thermophilic bacteria and archaea: mechanisms for reductant disposal. Environ Technol 2010;31(8-9):993-1003. https://doi.org/10.1080/ 09593331003710244.

[49] Belkin S, Wirsen CO, Jannasch HW. A new sulfur-reducing, extremely thermophilic eubacterium from a submarine thermal vent. Appl Environ Microbiol 1986:1180-5. 